\title{
APLIKASI PLTS ON GRID PADA USAHA PEMBESARAN LELE
}

\section{Fahru Nurosyid, Agus Supriyanto, Risa Suryana, Yofentina Iriani}

\author{
Jurusan Fisika, Fakultas Matematika dan Ilmu Pengetahuan Alam, Universitas Sebelas Maret, \\ Surakarta, Jawa Tengah, Indonesia, 57126 \\ Email: fahrunurosyid@staff.uns.ac.id
}

\begin{abstract}
ABSTRAK
Aplikasi PLTS on grid pada usaha pembesaran lele bertujuan untuk menurunkan biaya untuk pemenuhan energi listrik, meningkatkan pengetahuan dan melatih ketrampilan merakit PLTS on grid. Petani lele mengunakan energi listrik untuk menyalakan pompa air. PLTS on grid memungkinkan menghemat biaya listrik. Penggunaan PLTS on grid tidak memerlukan baterai penyimpan energi listrik. Kelebihan produksi listrik dari PLTS memungkinkan untuk dijual ke PLN. Bila terjadi kekurangan listrik, maka listrik dibeli dari PLN. Pengetahuan masyarakat tentang PLTS dapat dikenalkan secara teori dan praktek instalasi PLTS skala 2000 WP (watt peak). Penggunaan PLTS skala 2000 WP dapat menghasilkan 9,2 KWH/hari dalam kondisi cerah.
\end{abstract}

Kata kunci: lele, PLTS, on grid,

\begin{abstract}
Application of on-grid PLTS on the effort of catfish enlargement aims to reduce the cost for the fulfillment of electrical energy, increase knowledge and train the skills to assemble PLTS on grid. Farmers catfish use electrical energy to power the water pump. PLTS on grid enables saving on electricity costs. The use of on-grid PLTS does not require an electric storage battery. The overproduction of electricity from PLTS allows it to be sold to PLN. If there is a shortage of electricity, then electricity is purchased from PLN. Public knowledge about PLTS can be introduced in theory and practice of PLTS installation scale 2000 WP (watt peak). The use of 2000 WP can produce 9.2 KWH / day in sunny conditions.
\end{abstract}

Key words: catfish, solar panel, on grid

\section{PENDAHULUAN}

Aplikasi Pembangkit Listrik Tenaga Surya yang sedang berkembang saat ini yaitu jenis PLTS on grid Atau PLTS Hybrid, sedangkan model penggunaan baterai sudah kurang diminati. Aplikasi ini juga pernah dilaporkan oleh Ghenai (2018). Aplikasi on grid menarik untuk diaplikasikan karena faktor ekonomis (Ghaitha, 2017). Penggunaan teknologi on grid, memungkinkan listrik yang dihasilkan PLTS dapat diinjeksikan ke listrik PLN. Bila penggunaan listrik dari PLTS 


\begin{abstract}
mengalami kekurangan, maka kebutuhan dapat dipasok dari PLN. Sebaliknya, listrik PLTS berlebih dapat dipasok ke PLN. Saat ini memungkinkan terjadi jual beli listrik antara pemilik PLTS rumah tangga dengan PLN (Srisadad, 2012). Jumlah listrik yang ditransaksikan antara PLTS rumah tangga dan PLN dapat dihitung dengan KWH meter 'eksporimpor'. KWH meter 'ekspor-impor' ini dapat memisahkan antara listrik yang dihasilkan dari solar cell dengan

terutama untuk kebutuhan menyalakan pompa air. Pada kegiatan ini, tim pengabdi memilih masalah energi yang sebagai fokus masalah yang perlu dipecahkan. Solusi yang ditawarkan yaitu mengenalkan energi listrik alternatif lain. Pada kegiatan pengabdian ini, tim pengabdi menawarkan pemecahan masalah ini dengan mengenalkan PLTS on grid. Diharapkan petani bisa menurunkan biaya energi listrik dan petani dapat merakit PLTS sendiri.
\end{abstract} listrik yang berasal dari jaringan PLN. Guna menjembatani transaksi jual beli listrik tersebut, pemerintah mengeluarkan peraturan menteri (Permen) ESDM Nomor 19 Tahun 2016 tentang Pembelian Listrik dari PLTS oleh PLN. Peraturan Direksi PT. PLN (PERSERO) Nomor: 0733.K/DIR/2013 tentang Pemanfaatan Energi Listrik Dari Fotovoltaik Oleh Pelanggan PT. PLN (PERSERO), Peraturan Menteri (Permen) ESDM Nomor 19 Tahun 2016 tentang Pembelian Listrik dari PLTS oleh PLN.

Kelompok petani pembesaran lele mitra pengabdian membutuhkan listrik untuk menyalakan pompa air dengan daya 1,1 KW. Rata-rata pompa air tersebut menyala 8 jam/perhari. Kebutuhan listrik diperkirakan 8,8 KWH. Pada kondisi cuaca cerah, PLTS 2000 WP dapat menghasilkan 9,2 KWH/perhari efektif ( 8 jam), sehingga diharapkan PLTS 2000 WP dapat memenuhi kebutuhan listrik tersebut.

Masalah yang dihadapi oleh petani pembesaran lele antara lain tingginya harga pakan dan tingginya energi listrik yang dibutuhkan

\section{METODE PENGABDIAN}

\section{Pelatihan in class}

Pelatihan in class dilakukan dengan menjelaskan tentang PLTS secara sederhana dan merakit sebuah instalasi PLTS. Pelatihan dilakukan 1 kali tatap muka. Penjelasan difokuskan pada teori tentang sel surya, perubahan energi sinar matahari menjadi listrik, perhitungan kebutuhan kapasitas PLTS, suku cadang yang diperlukan, dan prosedur pengajuan perubahan $\mathrm{KWH}$ meter biasa menjadi KWH meter ekspor-impor.

\section{Pelatihan out class}

Pelatihan out class dilakukan beberapa kali tatap muka. Materi pelatihan ini meliputi: penyedian suku cadang yang diperlukan, posisi pemasangan panel surya, perakitan suku cadang menjadi rangkain PLTS on grid.

\section{Suku cadang PLTS on grid}

Panel surya $8 \times 250$ WP dimensi $100 \times 170 \mathrm{~cm} \times$, 2 buah microinverter on grid 1200 watt, 1 batang stainless steel 316 diameter $16 \mathrm{~mm}$ 
panjang $6 \mathrm{~m}$ sebagai ground, kabel ground diameter $8 \mathrm{~mm}$, kabel NYYHY $3 \times 2,5 \mathrm{~mm}$, rangka stainless steel, 1 buah MCB RCBO 10 A, 1 buah KWH meter.

\section{Lokasi dan waktu pengabdian}

Lokasi pengabdian masyarkat yaitu di desa Donohudan, kecamatan Ngemplak, kabupaten Boyolali, Jawa Tengah. Kegiatan dilakukan dalam kurun waktu 3 bulan.

\section{PEMBAHASAN}

\section{Transfer Ipteks}

Kegiatan ini dilakukan melalui pelatihan in class dan out class. Ipteks yang ditransferkan yaitu ilmu pengetahuan tentang cara kerja sel surya, estimasi biaya pemasangan PLTS, dan cara instalasinya. Transfer ipteks dijabarkan sebagai berikut:

Cara kerja sel surya. Cara kerja sel surya dijelaskan oleh tim pengabdi. Prinsip kerja sel surya dijelaskan pada Gambar 1.

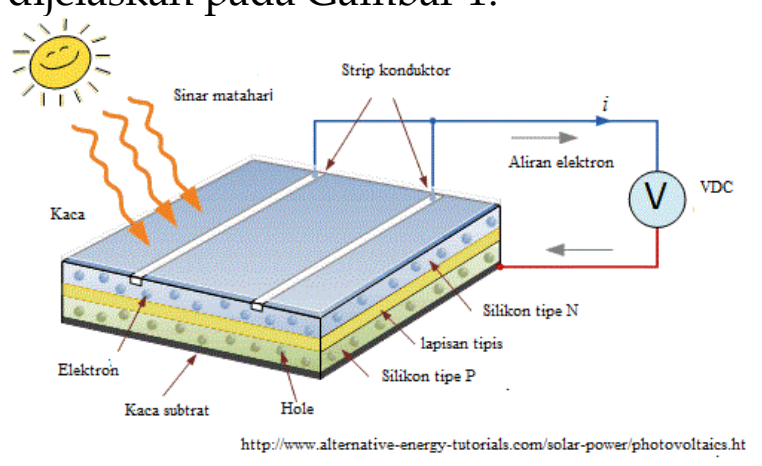

Gambar 1. Prinsip kerja sel surya
Ketika sinar matahari menyinari panel surya maka elektron pada pita valensi akan meloncat ke pita konduksi. Apabila sel surya dihubungkan dengan sirkuit luar maka akan terjadi gerakan elektron. Arus listrik yang dihasilkan pada sel surya merupakan arus DC. Agar dapat digunakan untuk listrik rumah tangga, maka arus DC harus diubah menjadi arus AC. Pengubahan ini dapat menggunakan alat inverter. Inverter ada 2 macam yaitu inverter off grid dan on grid. Inverter off grid memerlukan baterai untuk penyimpanan listriknya, sedangkan inverter on grid tidak memerlukan baterai. Listrik yang dihasilkan pada PLTS dengan inverter on grid dapat digabungkan dengan jaringan listrik PLN. Apabila produksi listrik berlebih maka listrik dapat dijual ke PLN dan apabila terjadi kekurangan listrik, maka listrik dapat dibeli dari PLN. Penghitungan transaksi jual-beli listrik antara PLN dan pelanggan dapat dihitung menggunakan meteran ekspor-impor. Untuk mendapatkan KWH meter ini perlu mengajukan ijin ke PLN.

$$
\text { Estimasi harga PLTS. }
$$

Pemasangan PLTS skala 2000 WP kira-kira memerlukan dana sekitar 51,765 juta rupiah. Rinciannya estimasi biaya disajikan pada Tabel 1 .

Tabel. 1 Asumsi rincian biaya pembuatan PLTS 2000 WP

\begin{tabular}{lr}
\hline \multicolumn{1}{c}{ Uraian } & $\begin{array}{c}\text { Asumsi harga } \\
\text { (Rp) }\end{array}$ \\
\hline Panel surya 2000 WP & 32.000 .000 \\
2 buah inverter 1200 watt & 10.000 .000 \\
Rangka Stainless steel 6 buah hollow 4 & 3.000 .000 \\
x 4 x 600 cm tebal 2 mm & 400.000 \\
25 m Kabel NYYHY 3 x 2,5 mm &
\end{tabular}




\begin{tabular}{lr} 
Ground & 1.000 .000 \\
2 m Kabel MC4 & 100.000 \\
MCB RSBO 10 A & 250.000 \\
KWH meter & 250.000 \\
Box panel & 150.000 \\
Jasa tukang (asumsi 10 \% dari biaya & 3.850 .000 \\
suku cadang) & $\mathbf{5 1 . 7 6 5 . 0 0 0}$ \\
\hline Jumlah & \\
\hline
\end{tabular}

PLTS 2000 WP perhari mampu menghasilkan 9,2 KWH dalam kondisi cuaca cerah. bila diasumsikan dalam satu tahun cuaca cerahnya 75 $\%$, maka dalam satu tahun dapat menghasilkan 2.518,5 KWH. Bila dihitung berdasarkan TDL Rp 1.352,/KWH (PERMEN ESDM RI No 28 Tahun 2016), maka dalam setahun PLTS menghasilkan Rp 3.405.012,-. Sehingga BEP pemasangan PLTS dapat dicapai dalam waktu kira-kira 15,2 tahun (bila tingkat cuaca cerah rata-rata $75 \%$ dalam tiap tahunnya). Umur PLTS bisa mencapai 20-25 tahun.

Instalasi PLTS. Pada kegiatan ini, PLTS dipasang di daerah Boyolali. Prinsipnya posisi panel surya menghadap datangnya sinar matahari. Untuk daerah Surakarta dan sekitarnya (termasuk Boyolali), sebaiknya posisi panel surya dipasang miring ke utara menghadap datangnya sinar matahari dengan sudut $19^{\circ}$ terhadap garis horisontal.
Pemasangan panel surya ditunjukkan pada Gambar 2.

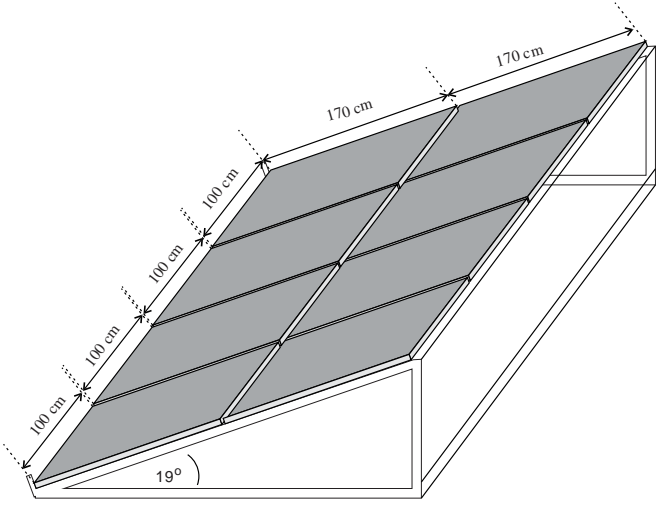

Gambar 2. Posisi kemiringan pemasangan panel surya untuk daerah Surakarta dan sekitarnya

Rangkaian PLTS 2000 WP dengan 2 buah inverter on grid 1200 watt. Kapasitas inverter dibuat lebih tinggi dari kemampuan panel surya, dengan tujuan agar bila terjadi lonjakan listrik yang dihasilkan tidak melampai batas kapasitas inverternya. Rangkain PLTS pada kegiatan ini ditunjukkan pada Gambar 3. 


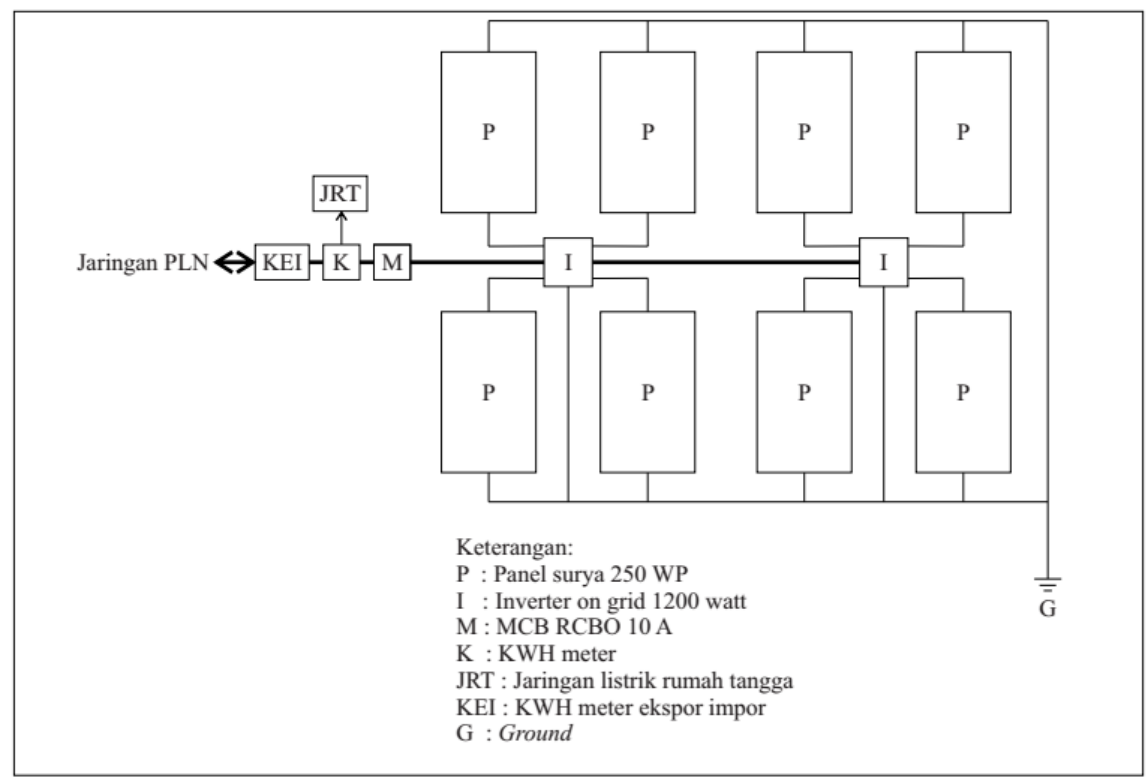

Gambar 3. Rangkaian PLTS 2000 WP on grid

\section{KESIMPULAN}

Kebutuhan listrik 9,2 KWH untuk usaha pembesaran lele di lokasi kegiatan pengabdian mayarakat dapat dipenuhi dengan PLTS on grid 2000 WP. Break even point pemasangan PLTS 2000 WP Boyolali yaitu 15,2 tahun dengan asumsi bila cuaca cerah setahun $75 \%$.

\section{UCAPAN TERIMA KASIH}

Terima kasih kami ucapkan kepada Universitas Sebelas Maret Surakarta yang telah mendanai kegiatan IbM melalui proyek Pengabdian Hibah IbM batch 2 sumber dana PNBP UNS Tahun Anggaran 2017.

\section{DAFTAR PUSTAKA}

Chaouki G C, Merabet A, Salameh T, Pigem EC. 2018. Grid-tied and stand-alone hybrid solar power system for desalination plant. Desalination, 435, 172-180.

Ghaitha AF, Epplina FM, dan Frazier, RS. 2107. Economics of grid-tied household solar panel systems versus grid-only electricity. Renew Sust Energ Rev, 76, 407424.

Ghaitha AF, Epplina FM, dan Frazier RS. 2107. Economics of grid-tied household solar panel systems versus grid-only electricity. Renew Sust Energ Rev, 76, 407424.

Ghenai C, Merabet A, Salameh T, Pigem EC. 2018. Grid-tied and stand-alone hybrid solar power system for desalination plant. Desalination, 435, 172-180.

http://www.alternative-energytutorials.com/solarpower/photovoltaics.html, Photovoltaic Solar Cells. diunduh pada 11 Oktober 2017. Peraturan Direksi PT. PLN (PERSERO) Nomor: 
ISSN : 1979-861X e-ISSN : 2549-1555

\begin{tabular}{ccc}
\hline \hline 0733.K/DIR/2013 tentang & Peraturan Menteri (Permen) ESDM \\
Pemanfaatan Energi Listrik Dari & Nomor 28 Tahun 2016 tentang \\
Fotovoltaik Oleh Pelanggan PT. & Tarif Tenaga Listrik Yang \\
PLN (PERSERO). & Disediakan oleh PT Perusahaan \\
Peraturan Menteri (Permen) ESDM & Listrik Negara (PERSERO). \\
Nomor 19 Tahun 2016 tentang & Srisadad G. 2012. Perancangan simulasi \\
Pembelian Listrik dari PLTS oleh & sistem rumah solar cerdas \\
PLN. & terhubung jaringan PLN. Skripsi, \\
& Universitas Indonesia.
\end{tabular}

